\title{
Growth of provenances of Cryptocarya alba during water stress and after re-watering in
} the nursery

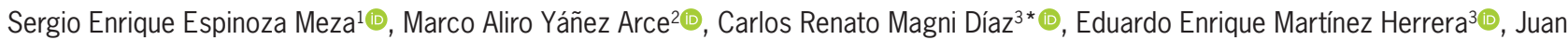
Francisco Ovalle Ortega ${ }^{3}$, Suraj Antonio Vaswani Miranda3(10)

Universidad Católica del Maule/Facultad de Ciencias Agrarias y Forestales, Av. San Miguel, 3605 - 3460000 Talca - Chile.

2Universidad de Talca/Núcleo Científico Multidisciplinario, 2 Norte 685 -, Casilla 747 - 3460000 - Talca - Chile. 3Universidad de Chile/ Facultad de Ciencias Forestales y de la Conservación de la Naturaleza - Depto. de Silvicultura y Conservación de la Naturaleza, Av. Santa Rosa, 11315 8820808 - Santiago - Chile.

*Corresponding author <crmagni@uchile.cl>

Edited by: Jason N. James

Received June 08, 2020

Accepted October 09, 2020
ABSTRACT: Intensification of drought in Mediterranean-type climates has limited seedling establishment. The knowledge of the ecology of selected species and its intraspecific variation to water stress at the seedling stage should be considered in order to overcome limitations. We investigated variations in growth, survival, and leaf-level physiology in four provenances of the endemic Cryptocarya alba (Mol.) during water stress and after re-watering. Seedlings were cultured in the nursery during 23 months and then subjected to two watering treatments based on soil water content (well-watered and water restriction, 0.38 and $0.17 \mathrm{~cm}^{3} \mathrm{~cm}^{-3}$, respectively) for 45 days. At the end of the watering treatments, seedling growth, above- and belowground biomass, survival, and leaf gas exchange were measured. Right after the watering treatments, the surviving seedlings were submitted to a recovery period of 21 days, in which all seedlings were re-watered at $0.38 \mathrm{~cm}^{3} \mathrm{~cm}^{-3}$ of soil water content and measured for leaf gas exchange. Provenances differed in growth and biomass allocation. Unlike growth and biomass, interaction between provenance and watering treatments was found for photosynthesis, stomatal conductance, transpiration, and water use efficiency of northern provenances, exhibiting the highest performance under water restriction. However, most variations observed occurred before the re-watering period and only a few occurred after this period. The four provenances under study exhibited similar photosynthesis and stomatal conductance after re-watering. Our study demonstrated phenotypic variation of $C$. alba and the capability of the species to withstand and recover from water stress.

Keywords: Sclerophyllus forests, seed sources, drought, plasticity, biomass allocation

\section{Introduction}

Water stress is a major cause of failure in Mediterraneantype forest ecosystems (Mendoza et al., 2009). Extreme drought events in the summer, when low water availability is accompanied by heat and high radiation (Garreaud et al., 2019), exacerbate mortality rate in the seedling establishment stage (Becerra et al., 2011; Ovalle et al., 2015). In order to estimate the relative capacity of a species to survive and grow under drought conditions, information on variations in the responses of seedlings to water stress is needed because of the highest mortality rate observed in seedling establishment of woody Mediterranean species (Davis, 1989).

One habitat that has been substantially degraded due to anthropogenic activities, and recently by fire (de la Barrera et al., 2018), is the endemic Cryptocarya alba (Mol.) Looser. (peumo) (Lauraceae), a native Mediterranean evergreen sclerophyllus tree species whose range of distribution spans over $10^{\circ}$ latitude $(1,150 \mathrm{~km}$ from semi-arid to humid zones in Chile) (Cabello and Donoso, 2013). The wide ecological distribution suggests that the species has high phenotypic variation and that different provenances may differ in their ability to withstand water stress. Knowing the variation in performance of different provenances could be useful in the selection of appropriate seed sources for restoration. Provenance differentiation to water stress has been largely investigated in sclerophyllus species growing in Mediterranean-type climates (Ducousso et al., 1996; Jensen and Hansen, 2008; Gratani et al., 2003; Ramírez-Valiente et al., 2010). Reduced leaf area (Baldochi and $\mathrm{Wu}, 2007$ ) and stomatal control over transpiration are key mechanisms to withstand water deficit (Mediavilla and Escudero, 2003; Fotelli et al., 2000). C. alba shows a lack of changes in the allocation of roots in relation to shoots as adaptive responses to water scarcity (Donoso et al., 2011; Ovalle et al., 2015). However, information on the amount and pattern of the responses in relation to seed-source provenance is scarce, causing concerns with potentially improper deployment of this species under the context of climate change. This study is aimed to assess the early response in survival, growth, biomass, and leaf-level physiological traits of four provenances of $C$. alba to water stress and rewatering under nursery conditions, representing various climate zones in central Chile. We tested the hypothesis that seedlings from drier provenances are better adjusted to water restricted conditions.

\section{Materials and Methods}

\section{Plant material}

Four provenances of $C$. alba with clear latitudinal-related climate differences were included in this study (Table 1). In 2017, we collected ripen fruits from trees with seed 
Table 1 - Location and climate parameters for four provenances of $C$. alba under study.

\begin{tabular}{|c|c|c|c|c|c|c|c|}
\hline Provenance (Location) & Köppen climate classification & Latitude & Longitude & Altitude & MAP & MAT & DM \\
\hline & & & & M & MM & ${ }^{\circ} \mathrm{C}$ & \\
\hline Colina (Interior) & Temperate Mediterranean with dry hot summer (Csb) & $33^{\circ} 03^{\prime} \mathrm{S}$ & $71^{\circ} 01^{\prime} \mathrm{W}$ & 1,122 & 381 & 13.1 & 16.5 \\
\hline Antumapu (Interior) & Temperate Mediterranean with dry hot summer (Csb) & $33^{\circ} 34^{\prime} \mathrm{S}$ & $70^{\circ} 07^{\prime} \mathrm{W}$ & 620 & 386 & 14.4 & 15.8 \\
\hline Cayumanque (Coastal) & Temperate, warm summers and cold winters (Cfb) & $36^{\circ} 42^{\prime} \mathrm{S}$ & $72^{\circ} 31^{\prime} W$ & 650 & 1,292 & 10.0 & 64.6 \\
\hline El Palpal (Interior) & Temperate, warm summers and cold winters ( $\mathrm{Cfb}$ ) & $36^{\circ} 57^{\prime} \mathrm{S}$ & $72^{\circ} 05^{\prime} \mathrm{W}$ & 180 & 1,228 & 12.8 & 53.9 \\
\hline
\end{tabular}

MAP $=$ Mean Annual Precipitation, MAT $=$ Mean Annual Temperature. DM $=$ De Martonne aridity index, estimated as MAP $/(M A T+10) \cdot$ MAP $=$ Mean Annual Precipitation, MAT = Mean Annual Temperature. DM = De Martonne aridity index, estimated as MAP/(MAT + 10).

abundance at each provenance. Each provenance was represented by a combination of open-pollinated families. Seeds were sown on Mar 2018 in $600 \mathrm{~mL}$ pots filled with local topsoil, sand, and coir coconut fiber $(2: 1: 1, \mathrm{v} / \mathrm{v})$, without fertilizer, and were cultured until Dec 2019 in a nursery located in the city of La Pintana, Chile $133^{\circ} 34^{\prime}$ $\mathrm{S}, 70^{\circ} 37^{\prime} \mathrm{W}$, altitude $\left.611 \mathrm{~m}\right)$. The daily irrigation regime was applied through an automatic irrigation system for all seedlings.

\section{Watering treatments and experimental design}

Two watering regimes were applied to seedlings for 45 days, water restriction treatment (WS) and well-watered treatment (WW). The soil water content was measured using portable temperature/moisture probes. Pots of WW treatment were kept at an average volumetric water content close to $0.38 \pm 0.05 \mathrm{~cm}^{3} \mathrm{~cm}^{-3}$, while in pots of WS treatment the average of volumetric water content was $0.17 \pm 0.07 \mathrm{~cm}^{3} \mathrm{~cm}^{-3}$. Three 14-day cycles of water withholding, plus one day of watering between each cycle, were applied in the WS treatment (45 days total). We arranged the experiment as a split-plot design. The watering regimes were the whole plot, while the provenances were the split-plot.

Water potential $\left(\Psi_{\mathrm{pd}}\right)$ was used to evaluate water status of seedlings and was measured by a Scholander pump. Seedlings of WW treatment were watered to keep a $\Psi_{\text {pd }}$ of $-0.9 \mathrm{MPa}$. In the WS treatment, seedlings reached a $\Psi_{\text {pd }}$ of $-3.7 \mathrm{MPa}$ on average. Based on Donoso et al. (2011), water restriction regimes were designed to inhibit, but not to stop completely, the growth and physiological activities of seedlings. After finishing the watering treatments, seedlings of the WW treatment and the surviving seedlings of the WS treatment (i.e., $33.3 \%$, Table 2) were re-watered at a volumetric water content similar to that of the WW treatment, that is, $\approx 0.38 \mathrm{~m}^{3}$ $\mathrm{m}^{-3}$, during 21 more days (mid Mar 2020) for assessing the gas exchange recovery capacity.

\section{Morphological assessments}

After WW and WS treatments had finished (Feb 2020) and before the re-watering period, we recorded seedling height $(\mathrm{H}, \mathrm{cm})$, root collar diameter $(\mathrm{D}, \mathrm{mm})$, and survival (SUR, binary response and then expressed as percentage). Increments for D (INCd) and $\mathrm{H}$ (INCh) were calculated as differences in those traits at the beginning and at the end of the watering treatments. After that, a subsample of seedlings was harvested and then oven-dried $\left(65^{\circ} \mathrm{C}\right.$, 48 h) to determine the dry mass of roots (RDW, mg), leaves (LDW, mg), stems (SDW, mg), and total mass (TDW, mg) per seedling. We derived the root:shoot ratio (RSR) as RDW/(SDW + LDW).

\section{Leaf-level physiological measurements}

After finishing the watering treatments and the rewatering period, we used five and three seedlings per experimental unit, respectively. Light-saturated photosynthesis $\left(\mathrm{A}_{\text {sat }}, u\right.$ mol $\left.\mathrm{CO}_{2} \mathrm{~m}^{-2} \mathrm{~s}^{-1}\right)$, transpiration

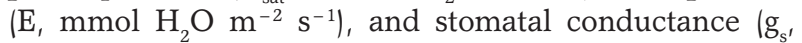
mol $\mathrm{H}_{2} \mathrm{O} \mathrm{m}^{-2} \mathrm{~s}^{-1}$ ) were recorded as the mean of three instantaneous measures per individual seedling. We estimated the intrinsic water use efficiency (WUE $_{\mathrm{i}}$ as the $A_{\text {sat }}$ to $g_{s}$ ratio. These measurements were taken in fully-developed leaves located on the upper third of the seedlings between $10 \mathrm{~h} 00$ and $12 \mathrm{~h} 00$ (local time) using a portable photosynthesis system. Measurements were done with saturated irradiance $1,600 \mu \mathrm{mol} \mathrm{m}^{-2} \mathrm{~s}^{-1}$, $\mathrm{CO}_{2}$ concentration $400 \mu \mathrm{mol} \mathrm{mol}^{-1}$ and molar flow rate $500 \mu \mathrm{mol} \mathrm{s}^{-1}$. Temperature was set at ambient conditions to $25^{\circ} \mathrm{C}$. Readings were taken once a steady state was achieved, usually close to $3 \mathrm{~min}$ per seedling. Data were logged once the system coefficient of variation $(\mathrm{CV})$ was $\leq 1 \%$.

\section{Statistical analysis}

We used the ANOVA to test the effects of watering treatment, provenance, and the interaction of these factors on seedling growth, increments for $\mathrm{D}$ and $\mathrm{H}$, biomass allocation, leaf-level physiology, and survival. The effect of the watering regime, provenance, and watering regime by provenance interaction were considered fixed, while the block effect was considered random. Post-hoc mean comparisons were based on the Tukey test at a probability level of $<0.05$. Differences in the initial seedling $\mathrm{H}$ and $\mathrm{D}$ between provenances before the implementation of the water experiments were tested with the t-test.

Because our interest was also to compare the gas exchange traits before and after re-watering, a model to assess the third order interaction of watering regime and provenance with time was performed, that is, the 


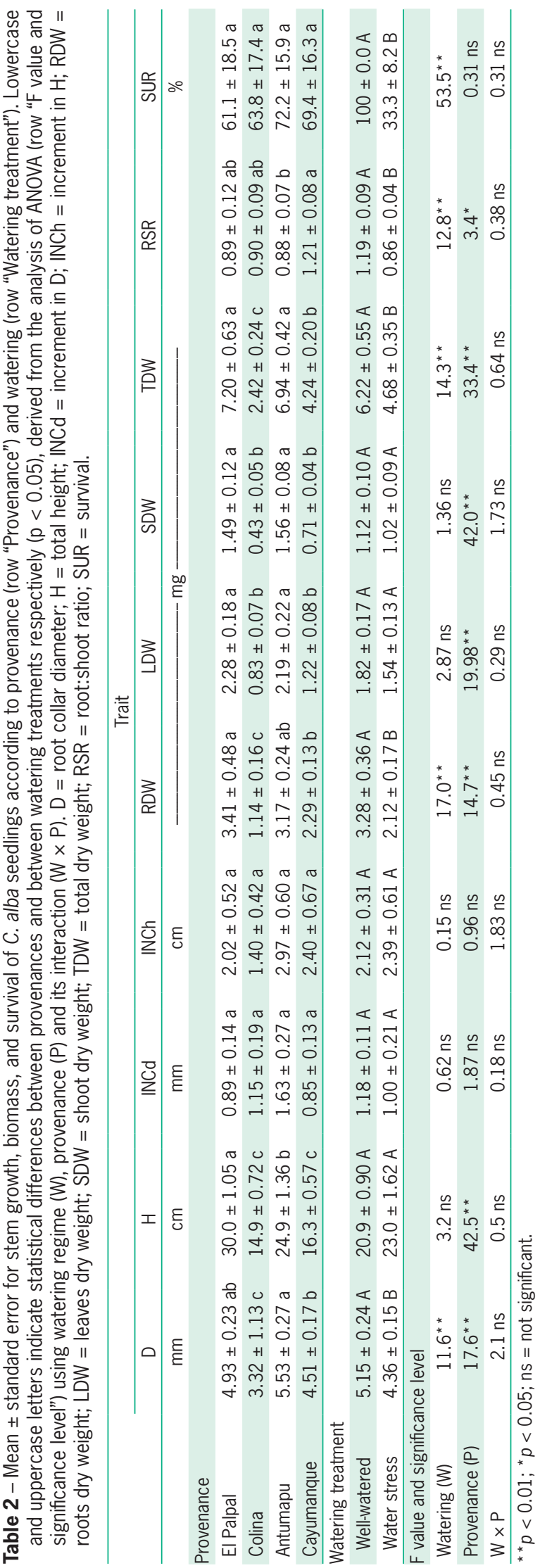

interaction between watering regime $x$ provenance $x$ time was added. In this case, the factor "time" refers to gas exchange traits for each provenance before and after re-watering. Additionally, the simple percentage variation was calculated by comparing the means of the provenances before re-watering to those after rewatering, with emphasis on the WS treatment, in order to highlight the changes in response to the recovery period.

\section{Results}

Before imposing the watering treatments, the provenances differed in initial D and $\mathrm{H}(p<0.05)$. The El Palpal provenance was the tallest $31.0 \pm 1.18 \mathrm{~cm}$ and $5.6 \pm$ $0.14 \mathrm{~mm}$ for $\mathrm{H}$ and $\mathrm{D}$, respectively), and the Antumapu provenance had the thickest $\mathrm{D}(24.0 \pm 0.97 \mathrm{~cm}$ and 6.5 $\pm 0.15 \mathrm{~mm}$ for $\mathrm{H}$ and $\mathrm{D}$, respectively). The Colina and Cayumanque provenances exhibited the lowest $\mathrm{H}$ and $\mathrm{D}$ $(\approx 16 \mathrm{~cm}$ and $3.5 \mathrm{~mm}$ for $\mathrm{H}$ and $\mathrm{D}$, respectively).

\section{Provenance effect on growth and biomass}

The provenance $\times$ watering interaction was not significant for the morphological traits nor for the survival (Table 2). After applying the differential watering regimes, differences in provenance growth in terms of $\mathrm{H}$ and D were kept throughout the experiment. Based on the main effects, El Palpal and Antumapu provenances showed greater stem growth and biomass than Colina and Cayumanque provenances, while there was no differences for survival and increments in $\mathrm{D}$ and $\mathrm{H}$. In the analysis of biomass, the Colina and Cayumanque provenances exhibited the lowest dry biomass (i.e., SDW, LDW and RDW), but the highest allocation of the total mass to belowground organs (i.e., high RSR). Conversely, the El Palpal and Antumapu provenances had higher body biomass (i.e., TDW) and exhibited a superior LDW (Table 2). The water stress treatment significantly reduced D, but not H, and decreased TDW, RDW, RSR, and SUR (Table 2).

\section{Provenance variation at the leaf-level physiology}

After the watering treatments were imposed, all gas exchange traits decreased significantly $(p<0.05)$ in the WS treatment compared with the WW treatment, and the provenance $\times$ watering interaction was significant for all the physiological parameters under study (Figure 1). The Antumapu provenance exhibited the highest and lowest $W_{U E}$ in the WW and WS treatments, respectively. The Cayumanque provenance had the highest $\mathrm{A}_{\text {sat' }} \mathrm{g}_{\mathrm{s}^{\prime}}$ and

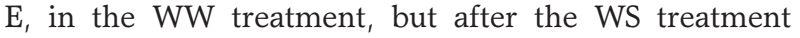
finished, $A_{\text {sat' }} g_{\mathrm{s}^{\prime}} E$ and $W U E_{i}$ were significantly higher in Colina provenance and lower in the El Palpal provenance (Figure 1). Interestingly, the Colina provenance exhibited similar $\mathrm{g}_{\mathrm{s}}$ and $\mathrm{E}$ in both watering treatments. At this time, $\mathrm{A}_{\text {sat }}$ in Colina provenance was almost two-fold higher than Antumapu and El Palpal provenances under water 
deficit. After 21 days of re-watering, provenances varied in $\mathrm{A}_{\text {sat }}$ by watering regime, and differed between time (i.e., after re-watering cf. before re-watering) in $\mathrm{E}$ and WUE. There was a lack of statistical significance for provenance by watering by time interaction for $\mathrm{A}_{\text {sat }}$ and $\mathrm{g}_{\mathrm{s}}$ (i.e., terms $\mathrm{W} \times \mathrm{P} \times \mathrm{T}$ of Table 3 ), meaning that, on average, all provenances exhibited similar physiological performance for these traits after re-watering (Figure 2 ). The percentage of recovery indicates that in the WS treatment the provenance Antumapu had the highest percentages of recovery in $\mathrm{A}_{\text {sat }}$ and $\mathrm{WUE}_{\mathrm{i}}$, while Colina provenance exhibited the opposite trend (Table 4).

\section{Discussion}

\section{Provenance effect on seedling growth and biomass}

The WS treatment resulted in significant decreases in survival and biomass. The water stressed seedlings, in which the container water availability was reduced
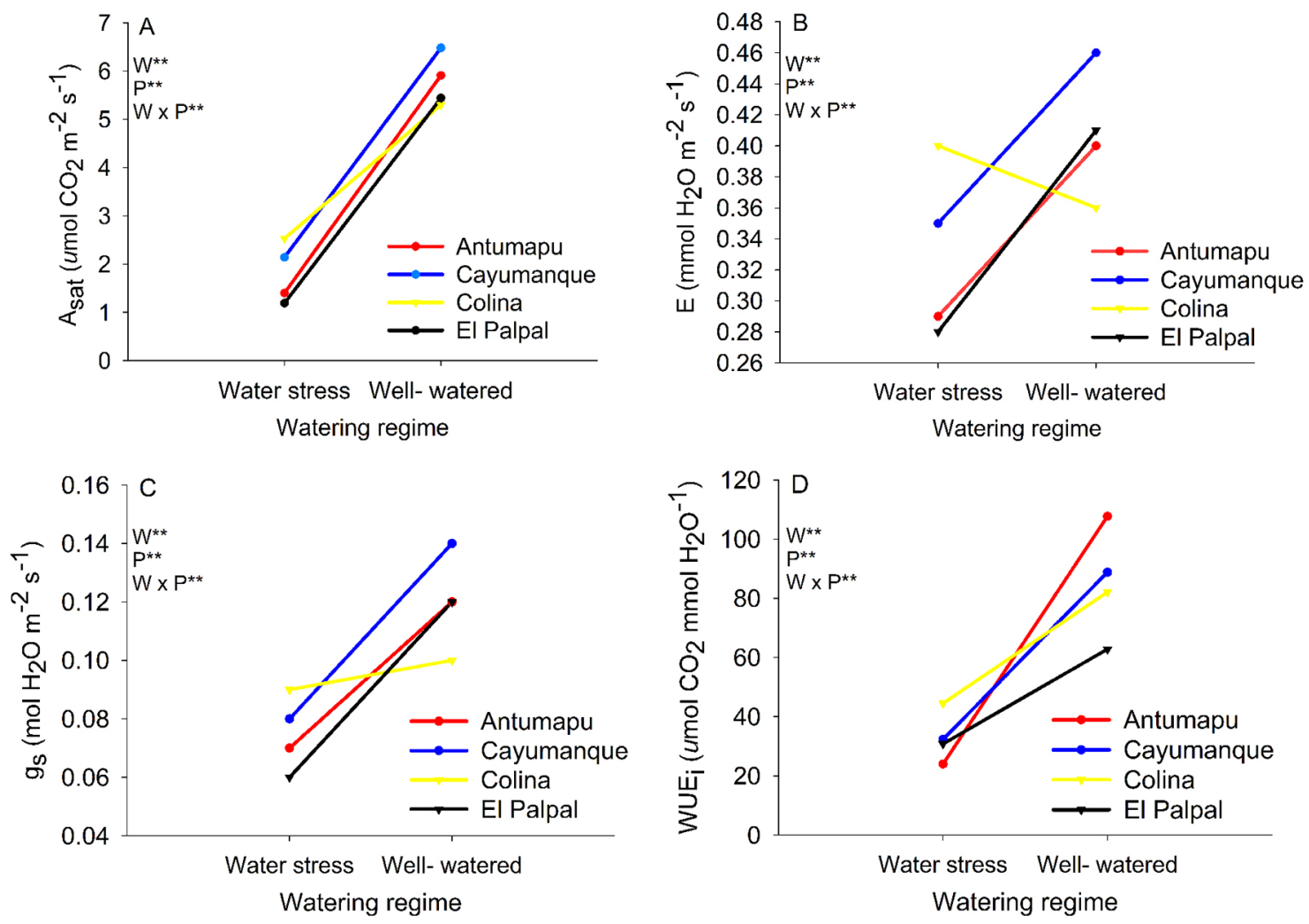

Figure 1 - Physiological traits of $C$. alba seedlings according to watering regime $(W)$, provenance $(P)$, and their interaction $(W \times P)$. $A_{\text {sat }}=L i g h t-$ saturated net photosynthesis rate; $\mathrm{E}=$ Transpiration; $\mathrm{g}_{\mathrm{s}}=$ Stomatal conductance; $\mathrm{WUE}_{\mathrm{i}}=$ Intrinsic water use efficiency; ${ }^{*}$ means significant at an alpha level of 0.01 .

Table 3 - F-value and significance from the analysis of variance conducted on C. alba seedlings before and after re-watering applied in WW and WS treatments. $A_{\text {sat }}=$ Light-saturated net photosynthesis rate; $E=$ Transpiration; $g_{s}=$ Stomatal conductance; and WUE $=$ Intrinsic water use efficiency. The effects are watering regime $(W)$, provenance $(P)$, and time $(T)$, that is, before and after recovery.

\begin{tabular}{lcccc}
\hline \multirow{2}{*}{ Effect } & \multicolumn{3}{c}{ Traits } \\
\cline { 2 - 5 } & $\mathrm{A}_{\mathrm{sat}}$ & $\mathrm{E}$ & $\mathrm{g}_{\mathrm{s}}$ & $\mathrm{WUE}_{\mathrm{i}}$ \\
\hline $\mathrm{Hmol} \mathrm{CO} \mathrm{m}^{-2} \mathrm{~s}^{-1}$ & $\mathrm{mmol} \mathrm{H}_{2} \mathrm{O} \mathrm{m}^{-2} \mathrm{~s}^{-1}$ & $\mathrm{~mol} \mathrm{H}_{2} \mathrm{O} \mathrm{m}^{-2} \mathrm{~s}^{-1}$ & $\mu \mathrm{mol} \mathrm{CO}_{2} \mathrm{mmol} \mathrm{H}_{2} \mathrm{O}^{-1}$ \\
$\mathrm{P}$ & $291.1^{* *}$ & $6.15^{* *}$ & $12.9^{* *}$ & $86.4^{* *}$ \\
$\mathrm{~T}$ & $5.24^{* *}$ & $5.11^{* *}$ & $0.77 \mathrm{~ns}$ & $0.66 \mathrm{~ns}$ \\
$W \times \mathrm{P}$ & $33.5^{* *}$ & $1.98 \mathrm{~ns}$ & $123.0^{* *}$ & $259.9^{* *}$ \\
$\mathrm{~W} \times \mathrm{T}$ & $5.95^{* *}$ & $1.74 \mathrm{~ns}$ & $1.02 \mathrm{~ns}$ & $0.65 \mathrm{~ns}$ \\
$\mathrm{P} \times \mathrm{T}$ & $56.7^{* *}$ & $2.05 \mathrm{~ns}$ & $25.0^{* *}$ & $6.97^{* *}$ \\
$\mathrm{~W} \times \mathrm{P} \times \mathrm{T}$ & $0.19 \mathrm{~ns}$ & $1.14 \mathrm{~ns}$ & $1.43 \mathrm{~ns}$ & $0.78 \mathrm{~ns}$ \\
${ }^{* *} \mathrm{p}<0.01 ;{ }^{*} p<0.05 ; \mathrm{ns}=$ not significant. & $1.44 \mathrm{~ns}$ & $2.84^{*}$ & $0.12 \mathrm{~ns}$ & $4.25^{* *}$
\end{tabular}



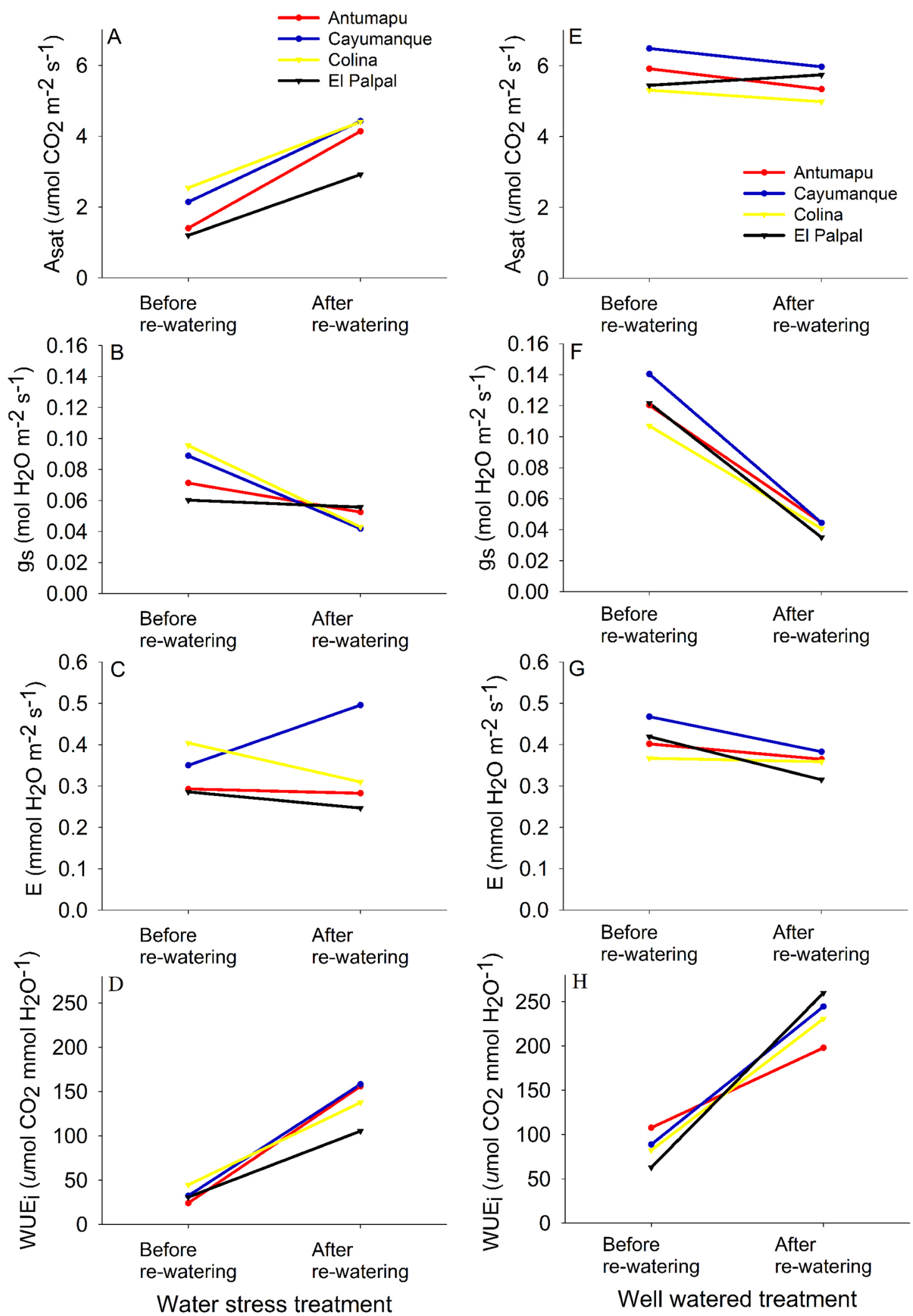

Figure 2 - Gas exchange values of $C$. alba seedlings before and after re-watering applied in WS and WW treatments. $A_{\text {sat }}=$ Light-saturated net photosynthesis rate; $\mathrm{E}=$ Transpiration; $\mathrm{g}_{\mathrm{s}}=$ Stomatal conductance; $\mathrm{WUE}_{\mathrm{i}}=$ Intrinsic water use efficiency. 
Table 4 - Percentage increases (+) and decreases (-) of the means of gas exchange traits of water stressed $C$. alba provenances after rewatering compared to those before re-watering. $A_{\text {sat }}=$ Light saturated net photosynthesis rate; $E=$ Transpiration; $g_{s}=$ Stomatal conductance; $\mathrm{WUE}_{\mathrm{i}}=$ Intrinsic water use efficiency.

\begin{tabular}{|c|c|c|c|c|}
\hline \multirow{2}{*}{ Provenance } & \multicolumn{4}{|c|}{ Trait } \\
\hline & $A_{\text {sat }}$ & $E$ & $g_{s}$ & WUE $_{i}$ \\
\hline & $\mu \mathrm{mol} \mathrm{CO}_{2} \mathrm{~m}^{-2} \mathrm{~s}^{-1}$ & $\mathrm{mmol} \mathrm{H} \mathrm{O} \mathrm{m}^{-2} \mathrm{~s}^{-1}$ & $\mathrm{~mol} \mathrm{H}_{2} \mathrm{O} \mathrm{m}^{-2} \mathrm{~s}^{-1}$ & $\mu \mathrm{mol} \mathrm{CO} \mathrm{mmol} \mathrm{H}_{2} \mathrm{O}^{-1}$ \\
\hline El Palpal & +144 & -14 & -7 & +242 \\
\hline Colina & +73 & -23 & -55 & +208 \\
\hline Antumapu & +195 & -4 & -26 & +547 \\
\hline Cayumanque & +106 & +42 & -53 & +389 \\
\hline
\end{tabular}

by $55 \%$, exhibited a reduction in RSR and in almost all traits analyzed, while LDW and SDW remained unaltered among the watering treatments. However, although $C$. alba is widely distributed over contrasting environmental conditions, no morphological variation was attributed to the effects of provenance $\times$ watering interaction. Donoso et al. (2011) conducted a nursery experiment with no information about seed provenance and observed that water stressed saplings exhibited a high osmotic adjustment (i.e., a tolerant strategy that allows tree species to keep water uptake under drought conditions); however, RSR remained unaltered among watering treatments. The RSR indicates the tradeoff between water extraction by the roots and transpiration by the shoots. Ovalle et al. (2015) found similar results in a field trial, that is, plants established without irrigation had similar RSR to those under irrigation. This suggests that drought resistance of the species is associated to tolerance strategies rather than to avoidance strategies, meaning that the provenances of $C$. alba under study were capable of keeping water uptake through osmotic adjustment rather than an investment in belowground biomass to explore for water; however, this contention needs to be investigated further.

On the other hand, and based on the analysis of main effects, significant variation was evident for stem growth and biomass traits, with both aboveground and belowground adaptations revealing a significant provenance effect. The provenances El Palpal and Antumapu kept the highest $\mathrm{H}$ and $\mathrm{D}$ throughout the experiment and exhibited the highest TDW, while Colina and Cayumanque were the provenances with the lowest LDW and highest RSR. As provenances growing in Mediterranean-type climates reduce leaf area as a mechanism to withstand water deficit (Baldochi and $\mathrm{Wu}$, 2007), the low LDW and high RSR of these provenances could imply a higher growth potential to acclimate to low soil moistures. Low LDW and high RSR reduce transpiration and contributes to keeping a favorable water balance for the whole plant. Lower LDW agrees well with the climate of Colina provenance, that is, Mediterranean-type ecosystem with low rainfall in which plants can develop smaller transpiration surfaces to avoid desiccation risk. However, lower LDW does not agree well with climate of Cayumanque provenance, a coastal provenance with high precipitation. In this study, due to the lack of climate data, we were not able to correlate provenance variation with environmental variables. As a mix of seeds collected from different mother trees represented each provenance, we believed that maternal effects on morphological variation could be a possible explanation for the differences detected; however, this hypothesis needs further research.

\section{Provenance variation to drought at the leaf-level physiology}

Our study clearly shows that leaf-level physiology of C. alba differs significantly among populations. Lortie and Aarssen (1996) theorized that genotypes adapted to unfavorable growing conditions might have superior performance in restrictive environments; however, they are unable to take advantage of favorable conditions. It seems that, before the re-watering period, the Colina provenance exhibited a behavior consistent with this theory, that is, a higher performance in almost all gas exchange traits in the WS treatment, but a lower performance in the WW treatment. Of the four provenances under study, the Colina provenance comes from a semiarid environment (Table 1) thus the superior WUE $_{\mathrm{i}}$ in the WS treatment was as expected (Whitehead et al., 1984; Cregg et al., 2000). Such response may imply a superior ability of this provenance in keeping photosynthesis under water deficit. This provenance showed similar $\mathrm{g}_{\mathrm{s}}$ and $\mathrm{E}$ in both watering treatments, which corroborates the specialization suggested by Lortie and Aarsen (1996) and an important stability for transpiration and stomatal control. Changes in $\mathrm{g}_{\mathrm{s}}$ and $\mathrm{E}$ between WS and WW treatment were $\approx 10 \%$ for Colina provenance, while El Palpal exhibited a rate of change close to $50 \%$. However, the gas exchange analyses after re-watering indicated that, with the exception of $\mathrm{E}$ and $\mathrm{WUE}_{\mathrm{i}}, \mathrm{A}_{\text {sat }}$ and $\mathrm{g}_{\mathrm{s}}$ were similar among provenances (i.e., interaction between $\mathrm{W} \times \mathrm{P} \times \mathrm{T}$ of Table 3 ) and suggested a capability of $C$. alba to withstand and recover from drought stress.

Overall, water-stressed plants recuperate up to $60 \%$ of photosynthesis after re-watering; however, they rarely recover to normal rates (Souza et al., 2004; Flexas et al., 2004). In our study, the recovery percentage for 
$\mathrm{E}$ and WUE after 21 days of rehydration was high and positive in Cayumanque and Antumapu provenances. It must be clarified that the highest percentages reported in Table 4 occurred because we estimated percentage of variation based on differences in the WS treatment only (i.e., Figure 2 panels A, B, C, D). Interestingly, both provenances exhibited the highest (but not significant) percentages of survival in the WS treatment. However, as we did not measure hourly or daily evolution during rehydration, we were not able to determine the recovery speed or to differentiate if recovery was mediated by acclimations factors of $C$. alba or by the severity of the water stress treatment. While some differences among provenances were found for physiological traits under WS conditions, they were not indicative of adaptation to climatic precipitation conditions for the $C$. alba provenances studied. Only the Colina provenance exhibited a behavior consistent with precipitation of the site of origin.

The ecological significance of our results suggests that the Colina provenance could have an adaptive advantage in tolerating drought stress. C. alba is a shade-tolerant and shallow-rooted species (Hoffmann and Kummerov 1978; Ovalle et al., 2015). Saplings of two years of age exhibited a water potential of -3.5 MPa in nursery conditions (Donoso et al., 2011), while trees exhibits water potentials of c.a. $-4.0 \mathrm{MPa}$ in the summer in natural stands (Giliberto and Estay, 1978). In our experiment, we simulated a water stress in which seedlings reached $-3.7 \mathrm{MPa}$, as a proxy of the severe conditions that climate change may impose to C. alba forests. Under these conditions, no differences in SUR were found among provenances; nevertheless, the Colina provenance exhibited the lowest leaf mass (LDW) of the experiment, probably depleting the pot water more slowly. This provenance also had the highest $\mathrm{WUE}_{\mathrm{i}}$ in the water stress treatment, which suggests they could be better adapted to severe drought conditions. Trubat et al. (2011) found that seedlings of the sclerophyllous Quercus coccifera L. with reduced size and leaf area had a superior performance than larger seedlings in a semi-arid site because small seedlings had a lower transpiration rate and better water use efficiency under drought. On the other hand, provenances El Palpal and Antumapu seem to be less adapted to severe drought. Both provenances produced larger seedlings with higher body mass, lower root:shoot ratio, and were the less water use efficient in the water stress treatment. Possibly, during severe drought years both provenances could be at risk of desiccation when facing drought because of their bigger transpiration surfaces. However, in mesic environments or during years with moderate to low drought conditions, these provenances could exhibit higher survival and growth, as observed in the evergreen sclerophyllous Quercus ilex L. because of the higher assimilation of carbohydrates associated with larger leaf areas (Villar-Salvador et al., 2004).

\section{Conclusions}

The results of this study demonstrated that provenance played a significant role in the early development of C. alba under different water stress regimes and a capability of the species to withstand and recover from water restriction. Seedlings from one of the driest provenances (Colina) seem to have a higher tolerance to drought, while one of the wettest provenances (El Palpal) showed a poorer drought adjustment. The ecological significance of our results could improve early establishment success predictions for different provenances of the species, allowing more reliable and cost-effective management decisions under climate change scenarios.

\section{Acknowledgments}

We thank the AngloAmerican Los Bronces operation for supporting this research. Special thanks to Nicole Toro, Betsabé Abarca and CESAF (Centro de Productor de Semillas y Árboles Forestales, Universidad de Chile) for their support in the nursery measurements.

\section{Authors' Contributions}

Conceptualization: Magni Díaz, C.R.; Martínez Herrera, E.E. Data acquisition: Espinoza Meza, S.E.; Vaswani Miranda, S.A. Data analysis: Espinoza Meza, S.E.; Yáñez Arce, M.A. Writing and editing: Espinoza Meza, S.E.; Yáñez Arce, M.A.; Magni Díaz, C.R; Martínez Herrera, E.E.; Ovalle Ortega, J.F.

\section{References}

Baldocchi, D.D.; Xu, L. 2007. What limits evaporation from Mediterranean oak woodlands: the supply of moisture in the soil, physiological control by plants or the demand by the atmosphere? Advances in Water Resources 30: 2113-2122.

Cabello, A.; Donoso, C. 2013. Cryptocarya alba (Mol.) Looser. (Peumo). Family: Lauraceae $=$ Cryptocarya alba (Mol.) Looser. (Peumo). Familia: Lauraceae. p. 205-211. In: Donoso, C., ed. Woody species in the temperate forests of Chile and Argentina: autoecology. Marisa Cuneo Ediciones, Valdivia, Chile (in Spanish).

Cregg, B.; Olivas-García, J.; Hennessey, T. 2000. Provenance variation in carbon isotope discrimination of mature ponderosa pine trees at two locations in the Great Plains. Canadian Journal of Forest Research 30: 428-439.

Davis, S.D. 1989. Patterns in mixed chaparral stands: differential water status and seedling survival during summer drought. p. 97-105. In: Keeley, S.C., ed. The California chaparral: paradigms reexamined. Natural History Museum, Los Angeles, USA.

de la Barrera, F.; Barraza, P.; Favier, Ph.; Ruiz, V.; Quense, J. 2018. Megafires in Chile 2017: monitoring multiscale environmental impacts of burned ecosystems. Science of the Total Environment 637-638: 1526-1536. 
Donoso, S.; Peña, K.; Pacheco, C.; Luna, G.; Aguirre, A. 2011. Physiological and growth response in Quillaja saponaria and Cryptocarya alba plants under restricted water conditions. Bosque 32: 187-195 (in Spanish, with abstract in English).

Ducousso, A.; Guyon, J.; Krémer, A. 1996. Latitudinal and altitudinal variation of bud burst in western populations of sessile oak (Quercus petraea (matt) Liebl). Annals of Forest Science 53: 775-782.

Flexas, J.; Bota, J.; Cifre, J.; Escalona, J.M.; Galmés, J.; Gulías, J.; Lefi, E.K.; Martínez-Cañellas, S.F.; Moreno, M.T.; Ribas-Carbó, M.T.; Riera, D.; Sampol, B.; Medrano, H. 2004. Understanding down-regulation of photosynthesis under water stress: future prospects and searching for physiological tools for irrigation management. Annals of Applied Biology 144: 273-283.

Fotelli, M.N.; Radoglou, K.M.; Constantinidou, H.I.A. 2000. Water stress responses of seedlings of four Mediterranean oak species. Tree Physiology 20: 1065-1075.

Garreaud, R.D.; Boisier, J.P.; Rondanelli, R.; Montecinos, A.; Sepúlveda, H.H.; Veloso-Aguila, D. 2019. The central Chile mega drought (2010-2018): a climate dynamics perspective. International Journal of Climatology 40: 421-439.

Giliberto, J.; Estay, H. 1978. Seasonal water stress in some chilean matorral shrubs. Botanical Gazette 139: 236-240.

Gratani, L.; Meneghini, M.; Pesoli, P.; Crescente, M.F. 2003. Structural and functional plasticity of Quercus ilex seedlings of different provenances in Italy. Trees 17: 515-521.

Hoffmann, A.; Kummerow, J. 1978. Root studies in the chilean matorral. Oecologia 69: 57-69.

Jensen, J.S.; Hansen, J.K. 2008. Geographical variation in phenology of Quercus petraea (matt.) Liebl and Quercus robur L. oak grown in a greenhouse. Scandinavian Journal of Forest Research 23: 179-188.
Lortie, C.J.; Aarssen, L.W. 1996. The specialization hypothesis for phenotypic plasticity in plants. International Journal of Plant Sciences 157: 484-487.

Mediavilla, S.; Escudero, A. 2003. Stomatal response to drought at a Mediterranean site: a comparative study of co-occurring woody species differing in leaf longevity. Tree Physiology 23: 978-996.

Mendoza, I.; Zamora, R.; Castro, J. 2009. A seeding experiment for testing tree-community recruitment under variable environments: implications for forest regeneration and conservation in Mediterranean habitats. Biological Conservation 142: 1491-1499.

Ovalle, J.F.; Arellano, E.C.; Ginocchio, R. 2015. Trade-offs between drought survival and rooting strategy of two south american mediterranean tree species: implications for dryland forests restoration. Forests 6: 3733-3747.

Ramírez-Valiente, J.A.; Sánchez-Gómez, D.; Valladares, F.; Aranda, I. 2010. Phenotypic plasticity and local adaptation in leaf ecophysiological traits of thirteen contrasting cork oak populations under different water availabilities. Tree Physiology 30: 618-627.

Souza, R.P.; Machado, E.C.; Silva, J.A.B.; Lagôa, A.M.M.A.; Silveira, J.A.G. 2004 Photosynthetic gas exchange, chlorophyll fluorescence and some associated metabolic changes in cowpea (Vigna unguiculata) during water stress and recovery. Environmental and Experimental Botany 51: 45-56.

Trubat, R.; Cortina, J.; Vilagrosa, A. 2011. Nutrient deprivation improves field performance of woody seedlings in a degraded semi-arid shrubland. Ecological Engineering 37: 1164-1173.

Whitehead, D.; Edwards, W.N.R.; Jarvis, P.G. 1984. Conducting area, foliage area and permeability in mature trees of Picea sitchensis and Pinus contorta. Canadian Journal of Forest Research 14:940-947. 